\title{
Development of a Survey Technique for Larvae of the Grass Webworm and Other Lepidopterous Species in Turfgrass ${ }^{1}$
}

\author{
H. TASHIRO,${ }^{2}$ C. L. MURDOCH,${ }^{3}$ AND W. C. MITCHELL \\ Department of Entomology, University of Hawaii, Honolulu, Hawaii 96822
}

\begin{abstract}
Environ. Entomol. 12: 1428-1432 (1983)
ABSTRACT Sampling techniques for larvae of the grass webworm, Herpetogramma licarsisalis (Walker) (Lepidoptera: Pyralidae) in turfgrass were studied. Sprinkling I liter of a $0.0015 \%$ aqueous solution of pyrethrins or $0.25 \%$ detergent into a $1,860-\mathrm{cm}^{2}$ frame forced 61 and $55 \%$ of the larvae to the surface, respectively, compared with 4 liters of each irritant. The need for a greater volume of water than the commonly used technique of applying 4 liters $/ 0.84 \mathrm{~m}^{2}$ was apparent. Continuous observation was required during the $10 \mathrm{~min}$ after application of either irritant to assure an accurate count, since $29 \%$ of the surfaced larvae reentered the thatch within 5 min and 38 to $39 \%$ reentered within 10 min. The detergent forced $>50 \%$ of the larve to surface within 2 min, compared with 4 min with pyrethrins. Liquid irritants surfaced ca. 3 times more larvae in 5 to $10 \mathrm{~min}$ than plywood set out overnight. Similar responses to the presence of minor populations of the lawn armyworm, the black curworm, and the fiery skipper indicate that other turf-infesting lepidopterous larvae may be sampled with the same techniques.
\end{abstract}

The grass webworm, Herpetogramma licarsisalis (Walker), is considered the most important lepidopterous pest of turfgrass in Hawaii (Tashiro 1976), followed in order of importance by the lawn armyworm, Spodoptera mauritia (Boisduval), the fiery skipper, Hylephila phyleus (Drury), and the black cutworm, Agrotis ipsilon (Hufnagle). An accurate and rapid method of determining larval populations in the turf is essential for studies on population dynamics and pest management, and for control studies.

One commonly employed procedure calls for the application of 1 gal (ca. 3.79 liters) of water containing either pyrethrins or a detergent over a square yard (ca. $0.8 \mathrm{~m}^{2}$ ) of turf with a sprinkling can. Larvae usually surface within $10 \mathrm{~min}$ (Anonymous 1981, Niemczyk 1981). Although this technique or slight modifications (Reinert 1976) have been in general use for some time, we are not aware of any research data from which this technique has evolved. Another technique used for sampling nocturnally feeding larvae in turfgrass has been to place plywood board ( 30.5 by 61 by $1.27 \mathrm{~cm}$ thick) on the turf during the evening before taking a reading (Mitchell and Murdoch 1974). Larvae that come to the surface to feed during the night remain at the surface, since the board excludes light. Larvae are easily counted the following morning by inverting the board.

We conducted various studies during February through June 1982 on 'Sunturf' bermuda, Cynodon magennissii Hurcombe, and 'Seashore' paspalum, Paspalum vaginatum Sw., turfgrass plots at the Waimanalo Field Station, Oahu. Efforts were made to modify and improve the currently used sampling techniques.

'Approved for publication by the Director, Hawaij Institute for Tropical Agriculture and Human Resources, as Journal Series No. 2738. Received for publication 1 February 1983; accepted 27 April 1983. Mention of a commercial or propietary product does not constitute an endorsement by the University of Hawaii.

${ }^{2}$ Visiting Entomologist, Dept. of Entomology. University of $\mathrm{Ha}-$ waii, on sabbatical leave from Cornell University, New York State: Agricultural Experiment Station, Geneva, NY 14456

${ }^{3}$ Dept. of Horticulture, University of Hawaii, Honolulu, HI 96822.

\section{Materials and Methods}

Moderately thatched turfgrass plots were maintained at a height of 1 to $2 \mathrm{~cm}$ and irrigated when needed. No distinction was made between testing on bermuda or paspalum, since larvae responded similarly in either grass. Test sites were selected primarily for high larval populations.

\section{Comparison of Boards, Submergence, and Sprinkling}

Six plywood boards ( 30.5 by 61 by $1.3 \mathrm{~cm}$ thick) were placed randomly on the turf during the previous evening as one of seven trcatments in a six-replication initial study. The next morning, the following six treatments were established in the vicinity of each board. Three steel cylinders $(20.3 \mathrm{~cm}$ in diameter by $20.3 \mathrm{~cm}$ high) with a cutting edge on one end were sunk through the turf into the surface soil. Each of the three cylinders received 4 liters of one of three treatments: water only, $0.002 \%$ pyrethrin, and $0.25 \%$ liquid detergent. These and all subsequent concentrations are on a vol/vol basis. Pyrenone containing $6.00 \%$ pyrethrins, $60.00 \%$ piperonyl butoxide, and $24.00 \%$ petroleum distillate (Fairfield American Corp.) was used in this and all subsequent tests. The detergent used for all tests was Joy, an anionic and nonionic surfactant plus ethyl alcohol (Procter and Gamble). Water containing these two materials is hereafter referred to as "liquid irritants." Standing water was present for $10 \mathrm{~min}$ in all three treatments. Each of three $0.84-\mathrm{m}^{2}$ areas was sprinkled with 4 liters of one of three liquids: water only, $0.002 \%$ pyrethrins, and $0.25 \%$ detergent. We counted the surfaced grass webworm larvae 10 min after treating. Larvae observed under each board were also recorded.

Since it required three settings of the 20.3-cm-diameter cylinders to obtain a $0.09-\mathrm{m}^{2}$ sample, use of these cylinders was not considered a highly practical sampling tool for webworms. A metal frame $(30.5$ by 61 by 7.6 $\mathrm{cm}$ high) fabricated from 3.2-mm-thick flat steel was $1,860 \mathrm{~cm}^{2}$ (Fig. IA). All four sides of one edge were tapered to a cutting edge. This was a more practical 

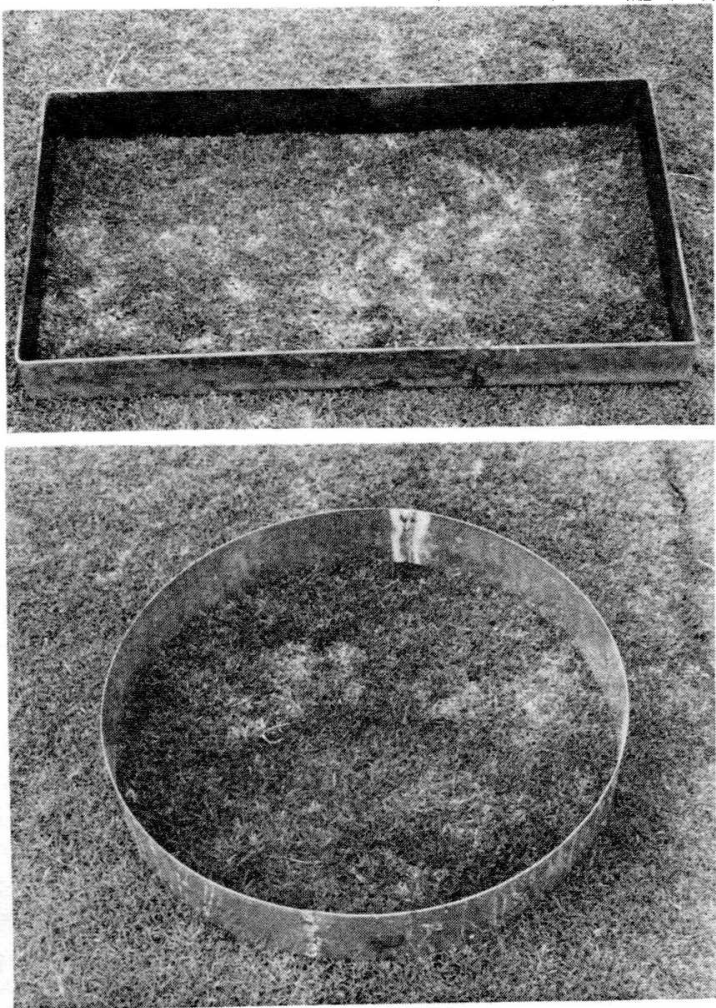

FiG. I. (A) Steel frame $(30.5$ by 61 by $7.6 \mathrm{~cm}$ ) occupying $1,860 \mathrm{~cm}^{2}$ and used for most sampling. (B) Sheet metal frame $\left(48.7 \mathrm{~cm}\right.$ in diameter) occupying $1,860 \mathrm{~cm}^{2}$.

sampling frame due to its larger size, but required a length of 2-by-4 lumber to be placed across the frame and a heavy hammer to force the cutting edge through the thatch into the surface soil. Most subsequent studies employed the use of such a frame.

\section{Concentrations of Irritant}

Four liters of water containing from 0.0004 to $0.006 \%$ concentration of pyrethrins (from 0.25 to $4.0 \mathrm{ml}$ of Pyrenone per 4 liters), and 0.063 to $1.000 \%$ concentration of detergent (from 2.5 to $40.0 \mathrm{ml}$ of Joy per 4 liters) was sprinkled within the metal frame. The same volume of water only was applied as the untreated control. Each of 11 treatments was replicated three times. We counted all larvae surfacing during the first $5 \mathrm{~min}$.

\section{Water Volume Requirement}

Application of 4 liters $/ 0.84 \mathrm{~m}^{2}$ of turfgrass, the standard technique, with either irritant appeared to be too small a volume for maximum surfacing in the initial test. Therefore, the use of 4 liters $/ 1,860 \mathrm{~cm}^{2}$ was compared with 1 liter $/ 1,860 \mathrm{~cm}^{2}$, which is roughly equivalent to 1 $\mathrm{gal} / \mathrm{yd}^{2}$. To keep the dose of pyrethrins and detergent constant, a $0.0015 \%$ pyrethrins and $0.25 \%$ detergent concentration was present in 4 liters, and $0.006 \%$ pyrethrins and $1.0 \%$ detergent concentration was present
Table 1. Relative efficiency of three techniques for surfacing grass webworm larvac in turfgrass with 4 liters per unit area ${ }^{\circ}$

\begin{tabular}{llc}
\hline \hline Technique & Irritant: \% concn & $\begin{array}{c}\text { Mean } \\
\text { larvae } / 1,860 \\
\mathrm{~cm}^{2 /}\end{array}$ \\
\hline & & \\
Cylinder $(20.3 \mathrm{~cm}$ in diam) & Water only & $24.8 \mathrm{a}$ \\
Cylinder $(20.3 \mathrm{~cm}$ in diam) & Detergent: $0.25 \%$ & $22.0 \mathrm{a}$ \\
Cylinder $(20.3 \mathrm{~cm}$ in diam) & Pyrethrin: $0.002 \%$ & $14.4 \mathrm{~b}$ \\
Board $(30.5$ by $61 \mathrm{~cm})$ & None & $12.4 \mathrm{bc}$ \\
Sprinkle $(91.4$ by $91.4 \mathrm{~cm})$ & Pyrethrin: $0.002 \%$ & $3.2 \mathrm{~cd}$ \\
Sprinkle $(91.4$ by $91.4 \mathrm{~cm})$ & Detergent: $0.25 \%$ & $1.2 \mathrm{~d}$ \\
Sprinkle $(91.4$ by $91.4 \mathrm{~cm})$ & Water only & $0 \mathrm{~d}$ \\
\hline
\end{tabular}

"Six replications per treatment

'Means followed by the same letter not significantly different at the $5 \%$ level (Waller and Duncan's multiple range test).

'Surface of turf submerged under standing water for $10 \mathrm{~min}$

in 1 liter of water. Five paired comparisons were made with a 5-min count for each sample.

\section{Board vs. Liquid Irritant}

With evidence early in these studies that the liquid irritants were more efficient in forcing larvae to surface than the boards, three different comparisons were made between the boards and liquids. In the first test, the boards $(30.5$ by $61 \mathrm{~cm}$ ) were put out during the previous day. On the following morning the surfaced larvae under the boards were counted and removed, and immediately thereafter the steel frame $(30.5$ by $61 \mathrm{~cm})$ was placed around the same area and sprinkled with 4 liters of water containing either $0.0015 \%$ pyrethrins or $0.25 \%$ detergent. Four comparisons were made with each irritant with a 5-min count of each sample.

A reciprocal of this study was made at another location. Larvae were forced to the surface with 0.007 , $0.0015,0.003$, and $0.006 \%$ pyrethrins and with 0.125 , $0.250,0.500$, and $1.0 \%$ detergent. Four liters of each was applied to each $1,860-\mathrm{cm}^{2}$ area within the frame, and larvae were counted during the first $5 \mathrm{~min}$. Immediately thereafter, the boards were placed over the same $1,860-\mathrm{cm}^{2}$ areas for counting surfaced larvae the following morning.

With evidence that not all larvae surface with liquid irritants in $5 \mathrm{~min}$, a third test was conducted with a 10 min count. Volume applied was the same as in the second test. With no evidence of concentration effects in test 2 , only the $0.0015 \%$ pyrethrins and $0.25 \%$ detergent were applied. After the 10-min counts the same 1,860$\mathrm{cm}^{2}$ areas were covered with boards and surfaced larvae counted the following morning.

\section{Rate of Larval Surfacing}

During the previous study it appeared that the detergent forced larvae to the surface quicker than pyrethrins. Also, since the generally accepted practice is to count larvae surfacing within the first $10 \mathrm{~min}$, it becomes important to determine the rate of surfacing, because periods less than $10 \mathrm{~min}$ would increase the efficiency of 
Table 2. Influence of irritant concentration in 4 liters of water per $1,860 \mathrm{~cm}^{2}$ on grass webworm larval surfacing in $5 \mathrm{~min}^{a}$

\begin{tabular}{lll}
\hline Irritant & $\%$ Concn & $\begin{array}{c}\text { Mean } \\
\text { larvae'1,860 } \\
\mathrm{cm}^{2 b}\end{array}$ \\
\hline Detergent & 1.000 & $21.0 \mathrm{bcd}$ \\
& 0.500 & $32.0 \mathrm{~b}$ \\
& 0.250 & $44.3 \mathrm{a}$ \\
& 0.125 & $26.7 \mathrm{bc}$ \\
Pyrethrins & 0.063 & $25.7 \mathrm{bc}$ \\
& 0.006 & $24.3 \mathrm{bc}$ \\
& 0.003 & $28.3 \mathrm{bc}$ \\
& 0.0015 & $26.3 \mathrm{bc}$ \\
& 0.0007 & $17.0 \mathrm{~cd}$ \\
Water ondy & 0.004 & $2.0 \mathrm{de}$ \\
& 0.0 & \\
\hline
\end{tabular}

Three replications per treatment.

Means followed by the same letter are not significantly different at the $5 \%$ level (Waller and Duncan's multiple range test).

Table 3. Influence of volume of irritants per $1,860 \mathrm{~cm}^{2}$ of turf on webworm larval surfacing in $5 \mathbf{~ m i n}^{\circ}$

\begin{tabular}{clcc}
\hline $\begin{array}{c}\text { Liters of } \\
\text { irritanv } 1,860 \\
\mathrm{~cm}^{2}\end{array}$ & $\begin{array}{c}\text { Irritant (\% } \\
\text { concn) }\end{array}$ & $\begin{array}{c}\text { Mean } \\
\text { larvae/1,860 } \\
\mathrm{cm}^{2 b}\end{array}$ & $\begin{array}{c}\text { I Liter } \\
\% \text { of } \\
4 \text { liters }\end{array}$ \\
\hline & & & \\
4.0 & Detergent $(0.25)$ & $27.4 \mathrm{a}$ & - \\
4.0 & Pyrethrins $(0.0015)$ & $25.5 \mathrm{a}$ & - \\
1.0 & Detergent $(1.00)$ & $14.6 \mathrm{~b}$ & 53 \\
1.0 & Pyrethrins (0.006) & $15.5 \mathrm{~b}$ & 61 \\
\hline
\end{tabular}

aFive replications per treatment.

-Means followed by the same letter are not significantly different at the $5 \%$ level (Waller and Duncan's multiple range test).

the sampling technique. A 4-liter amount of $0.0015 \%$ pyrethrin and $0.25 \%$ detergent was applied inside the $1,860-\mathrm{cm}^{2}$ frame. Surfacing larvae were counted and removed at 1 -min intervals for $10 \mathrm{~min}$. Each of the two treatments was replicated seven times.

\section{Fate of Surfaced Larvae}

With indication in the standard procedures that larvae surface within $10 \mathrm{~min}$, there may be a tendency to wait
10 min after application of irritant solutions to make counts. This may produce erroneous counts should surfaced larvae reenter the thatch. A test was conducted to resolve this question. Four liters of $0.0015 \%$ pyrethrins or $0.25 \%$ detergent solutions was applied within each $1,860 \mathrm{~cm}^{2}$ frame setting. There were five settings for each irritant. As each larva surfaced, its position was marked with a toothpick inserted into the thatch or soil. As a larva disappeared the representing toothpick was removed. Five and $10 \mathrm{~min}$ after application the numbers of larvac still remaining on the surface as represented by remaining toothpicks were counted.

\section{Miscellaneous Studies and Observations}

Common liquid detergents, Ivory and Wisk, were compared with Joy at the same concentration of $0.25 \%$ in 4 liters $/ 1,860 \mathrm{~cm}^{2}$. Two powders, All and Alconox (for cleaning laboratory glassware), were also tried at $1.5 \%$ concentration in 4 liters $/ 1,860 \mathrm{~cm}^{2}$.

Essentially all of the sampling studies after the initial test were conducted by using the metal frame $(30.5$ by 61 by $7.6 \mathrm{~cm}$ ) forced through the thatch and partially into the surface soil to retain most of the 4 liters of water applied. Limitations in this technique were the need for a heavy hammer and a length of 2-by-4 lumber to lay across the frame for hammering. This prompted a limited observation in the use of a $48.7-\mathrm{cm}$-diameter circular frame $7.6 \mathrm{~cm}$ high (also occupying an area of $1,860 \mathrm{~cm}^{2}$ ) made from light sheet metal (Fig. 1B). In addition to its lightness it had an additional advantage in occupying the smallest possible dimensions.

In addition to the extensive studies made on the grass webworm, a few larvae of three other lepidopterous pests of turfgrass were present-the lawn armyworm, the black cutworm, and fiery skipper. Their response to the various sampling techniques was also noted.

\section{Results and Discussion}

\section{Comparison of Boards, Submergence, and Sprinkling}

Results of this test comparing overnight response to boards ( 30.5 by $61 \mathrm{~cm})$, cylinders $(20.3 \mathrm{~cm}$ in diameter) with standing water, and sprinkling 4 liters onto an 0.84 -

Table 4. Comparison of liquid irritants and boards in sampling grass webworm larval populations"

\begin{tabular}{|c|c|c|c|c|c|}
\hline \multirow{2}{*}{ Test ${ }^{b}$} & \multirow{2}{*}{$\begin{array}{l}\text { Sampling sequence } \\
\text { (initial-follow up) }\end{array}$} & \multicolumn{3}{|c|}{ Mean larvae/samplec } & \multirow{2}{*}{$\begin{array}{c}\text { \% of } \\
\text { total by } \\
\text { initial }\end{array}$} \\
\hline & & Board & Irritant & Total & \\
\hline \multirow[t]{2}{*}{1} & Board-detergent ${ }^{d}$ & $8.3 \mathrm{a}$ & $24.3 c$ & $32.6 d$ & 25 \\
\hline & Board-pyrethrins & $7.0 \mathrm{a}$ & $15.3 b$ & $22.3 \mathrm{c}$ & 31 \\
\hline \multirow[t]{2}{*}{2} & Detergent-boardd & $3.0 \mathrm{a}$ & $26.7 \mathrm{c}$ & $29.7 c$ & 90 \\
\hline & Pyrethrins-board ${ }^{d}$ & $1.7 \mathrm{a}$ & $15.5 b$ & $17.2 \mathrm{~b}$ & 92 \\
\hline \multirow[t]{2}{*}{3} & Detergent--boardr & $1.3 \mathrm{a}$ & $15.3 b$ & $16.6 \mathrm{~b}$ & 93 \\
\hline & Pyrethrins-board ${ }^{p}$ & $0.5 \mathrm{a}$ & $20.0 c$ & $20.5 \mathrm{c}$ & 98 \\
\hline
\end{tabular}

aFour replicatations per treatment per test.

'Sampling different populations in each test.

Means in each test followed by the same letter are not significantly different at the $5 \%$ level (Waller and Duncan's multiple range test).

d Five-minute sampling period.

Ten-minute sampling period. 
Table 5. Effect of liquid irritants on rate of grass webworm larval surfacing in turf

\begin{tabular}{|c|c|c|c|c|}
\hline \multirow{2}{*}{$\begin{array}{l}\text { Time (min) after } \\
\text { application }\end{array}$} & \multicolumn{2}{|c|}{ Mean larvae/min } & \multicolumn{2}{|c|}{$\begin{array}{c}\text { Accumulated } \\
\% \text { of total }\end{array}$} \\
\hline & $\begin{array}{c}\text { Detergent } \\
0.25 \% \text { concn }\end{array}$ & $\begin{array}{c}\text { Pyrethrins } \\
0.0015 \% \text { concn }\end{array}$ & Detergent & Pyrethrins \\
\hline 1 & 8.6 & 1.7 & 39 & 7 \\
\hline 2 & 3.6 & 2.6 & 55 & 17 \\
\hline 3 & 2.0 & 5.1 & 64 & 37 \\
\hline 4 & 2.7 & 4.1 & 76 & 52 \\
\hline 5 & 1.9 & 3.0 & 85 & 64 \\
\hline 6 & 1.6 & 2.6 & 92 & 74 \\
\hline 7 & 0.7 & 3.1 & 95 & 86 \\
\hline 8 & 0.4 & 1.9 & 97 & 93 \\
\hline 9 & 0.6 & 1.0 & $99+$ & 97 \\
\hline 10 & 0 & 0.7 & $99+$ & 100 \\
\hline Mean total & 22.1 & 25.8 & & \\
\hline
\end{tabular}

aSeven replications per irritant per minute. All samples of $1: 860 \mathrm{~cm}^{2}$ within frame $(30.5 \mathrm{by} 61 \mathrm{~cm})$, and 4 liters per setting.

$\mathrm{m}^{2}$ area are summarized (Table 1 ) with data converted to larvae per $1,860 \mathrm{~cm}^{2}$. Complete submergence with standing water $(10 \mathrm{~min})$ was the most effective, with no difference between water alone and $0.25 \%$ detergent. A $0.0015 \%$ pyrethrins solution was less effective. The boards were intermediate in effectiveness. Treatments with 4 liters of water over a $0.84-\mathrm{cm}^{2}$ area were the least effective, with water alone not forcing any larvae to the surface. Several definite opinions were formed as a result of this test. Although the cylinders with standing water were the most effective whether an irritant was added or not, a $20.3-\mathrm{cm}$-diameter cylinder is not considered a practical size for grass webworm larval sampling, since it would take three settings to occupy a $0.09-\mathrm{m}^{2}$ area. This test also convinced us that $0.84 \mathrm{~m}^{2}$ of turf is too large an area for one person to observe over a period of time with accuracy. It also appeared that 4 liters of water over $0.84 \mathrm{~m}^{2}$ was insufficient to adequately soak the turf with either irritant.

For a practical and efficient technique, it appeared that we should decrease the area to be observed from $0.84 \mathrm{~m}^{2}$ to an area not to exceed $1,860 \mathrm{~cm}^{2}$ and maintain the water volume at 4 liters for complete saturation.

Table 6. Fate of grass webworm larvae forced to surface in turf with liquid irritants"

\begin{tabular}{llll}
\hline \hline Irritant $\left(\%\right.$ concn) ${ }^{b}$ & $\begin{array}{c}\text { Counting period } \\
\text { (in min) }\end{array}$ & $\begin{array}{c}\text { Mean larvae } \\
\text { surfacing or } \\
\text { remaining }\end{array}$ & $\begin{array}{c}\% \\
\text { Reentered }\end{array}$ \\
\hline & & & \\
Detergent (0.25) & First 5 & $26.4 \mathrm{a}$ & - \\
& At 5 & $19.0 \mathrm{~b}$ & 29 \\
& At 10 & $16.2 \mathrm{~b}$ & 39 \\
Pyrethrins (0.0015) & First 5 & $52.6 \mathrm{a}$ & - \\
& At 5 & $37.6 \mathrm{~b}$ & 29 \\
& At 10 & $33.0 \mathrm{~b}$ & 38 \\
& & & \\
\hline
\end{tabular}

"Five replications per treatment.

bSampling different populations for each irritant. All samples of 1,860 $\mathrm{cm}^{2}$ within frame $(30.5$ by $61 \mathrm{~cm})$ and 4 liters per setting.

'Means for each irritant followed by the same letter are not significantly different at the $5 \%$ level (Waller and Duncan's multiple range test).

\section{Concentration of Pyrenone and Detergent}

The application of $0.0004,0.0007,0.0015,0.003$, and $0.006 \%$ pyrethrins showed that the two lowest concentrations were less effective than the three higher concentrations (Table 2). The $0.25 \%$ detergent was the most effective. The highest concentration of $1.0 \%$ provided the least response with evidence of slight temporary toxicity. Surfacing larvae immediately became rigid and immobile but recovered within 5 to $10 \mathrm{~min}$. The $0.0015 \%$ pyrethrins and $0.25 \%$ detergent solutions were standardized for further testing.

\section{Water Volume Requirements}

When we were convinced that 4 liters of water per $0.84 \mathrm{~m}^{2}$ was an insufficient volume for complete saturation of the turf, the effects of 4 liters $/ 1,860 \mathrm{~cm}^{2}$ were compared with those of 1 liter $/ 1,860 \mathrm{~cm}^{2}$. Volumes of pyrethrins and detergent were quadrupled for the liter applications to maintain the same volume of active ingredient at each site. The results (Table 3 ) show a need to have the larger volume of water whether pyrethrins or detergent is used. One liter of water per $1,860 \mathrm{~cm}^{2}$ forced up only 61 and $53 \%$ of the numbers foreed up with 4 liters of pyrethrins and detergent, respectively, per $1,860 \mathrm{~cm}^{2}$.

\section{Boards vs. Liquid Irritants}

Of the total population considered present in four areas of $1,860 \mathrm{~cm}^{2}$, the boards showed only $31 \%$ efficiency of pyrethrins and $25 \%$ efficiency of the detergent (Table 4). In a reciprocal test of forcing larvae with the liquid irritants first, then counting under the boards in the same area, it was apparent that the irritants did not force all the larvae to the surface. Pyrethrins forced $92 \%$ of the larvae to the surface, whereas the detergent forced $90 \%$ of the larvae to the surface during a 5-min count.

Even though pyrethrins and detergent solutions were highly effective when applied at 4 liters $/ 1,860 \mathrm{~cm}^{2}$, there were indications that not all the larvae were forced to the surface in $5 \mathrm{~min}$. Therefore, the number of larvae 
surfacing over a 10 -min period was determined before covering the same areas with boards. Under these conditions, pyrethrins had a $98 \%$ efficiency and the detergent a $93 \%$ efficiency.

\section{Rate and Duration of Larval Surfacing}

Since it became evident that a period of about $10 \mathrm{~min}$ was required to force virtually the entire larval population to the surface, counts were made of surfacing larvae at 1 -min intervals for the entire 10 -min period. Four liters of $0.25 \%$ solution of detergent per $1,860 \mathrm{~cm}^{2}$ of turf was more effective than the $0.0015 \%$ pyrethrins in the rapidity of forcing larvae to surface. Within $2 \mathrm{~min}$, $>50 \%$ of the total population present surfaced with the detergent, whereas it took up to $4 \mathrm{~min}$ for the same percentage to surface with pyrethrins (Table 5). The same relative differences held for surfacing between 90 and $95 \%$ of the total population.

\section{Fate of Surfaced Larvae}

Evidence in several studies pointed to the need for constant observation to obtain an accurate count of the total larval population since some disappeared from the surface. By marking every larva that surfaced during the first $5 \mathrm{~min}$ and then determining numbers still on the surface at 5 and $10 \mathrm{~min}$ after treating, it was determined that $29 \%$ of the surfaced larvae had reentered the thatch after $5 \mathrm{~min}$ and $38 \%$ after $10 \mathrm{~min}$ (Table 6) when 4 liters of $0.0015 \%$ pyrethrin per $1,860 \mathrm{~cm}^{2}$ was used. Reentry was nearly identical with 4 liters of $0.25 \%$ detergent per $1,860 \mathrm{~cm}^{2}$ with $29 \%$ reentry in $5 \mathrm{~min}$ and 38 to $39 \%$ in 10 min. Results of this experiment give ample evidence that observations must be continuous for the entire examination period to obtain accurate counts.

\section{Miscellaneous Studies and Observations}

All three liquid detergents, Joy, Ivory, and Wisk, and the two powders, All and Alconox, used at the same concentrations of $0.25 \%$ for liquids and $1.5 \%$ for powders, and same volume of 4 liters $/ 1,860 \mathrm{~cm}^{2}$, were equally effective in limited trials.

Because of the need to have a heavy hammer and a short length of 2-by-4 board to set the heavy steel frame $(30.5$ by $61 \mathrm{~cm}$ ) deep enough through the hatch to retain nearly all the water added, sprinkling the 4 liters of water into the frame without sealing to prevent water loss was a practical compromise. Even though there was seepage outside the frame with subsequent surfacing of larvae, the thorough saturation within the frame was as effective as retaining all the water. A circular, thin sheet metal frame of $48.7 \mathrm{~cm}$ in diameter occupying 1,860 $\mathrm{cm}^{2}$ had the added advantage of occupying the smallest dimension in sampling $1,860 \mathrm{~cm}^{2}$ of turf.

We conclude from these tests that the most efficient features to employ for efficient sampling of lepidopterous larval populations in turfgrass should include the following features: to have an examination area of 1,860 $\mathrm{cm}^{2}$, preferably in a circular configuration; 4 liters of water containing either $0.0015 \%$ pyrethrins or $0.25 \%$ detergent should be sprinkled within the frame for even distribution; observations for surfacing larvae should be continuous during the first $5 \mathrm{~min}$ for a count of ca. $90 \%$ of the population present, or preferably for $10 \mathrm{~min}$ for a count of virtually $100 \%$ of the larvae present.

The few larvae present of the lawn armyworm, the fiery skipper, and the black cutworm responded identically to the liquid irritants, as did the grass webworm. Therefore, we assume that these improved techniques are adaptable for use against most species of lepidopterous larvae infesting turfgrass.

\section{Acknowledgment}

J. Y. Kuniyoshi and S. Higa of the Agricultural Engineering Department, University of Hawaii, fabricated the steel cylinders, the frames, and the circular frame mentioned above. We are grateful for these contributions to this study.

\section{REFERENCES CITED}

Anonymous. 1981. Guide to turfgrass pest control (to be used with Turfgrass Pests, Priced Publication 4053). Div. Agric. Sci. Univ. Calif. Leafl. 2209. 18 pp.

Mitchell, W. C., and C. L. Murdoch. 1974. Insecticides and their application frequency for control of turf insects in Hawaii. Down Earth 30: 17-23.

Niemczyk, H. D. 1981. Destructive turf insects. HDN Books, Wooster, Ohio. $48 \mathrm{pp}$.

Reinert, J. A. 1976. Control of sod webworms (Herpetogramma spp. and Crambus spp.) on bermudagrass. J. Econ. Entomol. 69: 669-672.

Tashiro, H. 1976. Biology of the grass webworm, Herpetogramma licarsisalis (Lepidoptera: Pyralidae) in Hawaii. Ann. Entomol. Soc. Am. 69: 797-803. 